\title{
UJI AKTIVITAS KOMBINASI EKSTRAK KERING LIDAH BUAYA (Aloe vera. (L) brum. $f$.) DAN EKSTRAK KENTAL DAUN SIRIH MERAH (Piper crocatum ruiz \& pav) UNTUK ANTIBAKTERI PENYEBAB JERAWAT
}

\author{
${ }^{1}$ Suhaimi, ${ }^{2}$ Teti Indrawati, ${ }^{3}$ Shirly Kumala \\ ${ }^{1}$ Mahasiwa, Fakultas Farmasi, Universitas Pancasila, Jakarta \\ Jl. Srengseng Sawah, Jagakarsa, Jakarta \\ ${ }^{2}$ Fakultas Farmasi, Universitas Pancasila, Jakarta \\ Jl. Srengseng Sawah, Jagakarsa, Jakarta
}

\section{INTISARI}

Ekstrak kering lidah buaya dan ekstrak kental daun sirih merah mengandung senyawa alkaloid, flavonoid, tanin, saponin dan fenol yang mempunyai aktivitas sebagai antibakteri penyebab jerawat. Penelitian ini bertujuanUntuk menentukan konsentrasi ekstrak kering lidah buaya (Aloe vera $(L)$ brum $f$ ), untuk menentukan ekstrak kental daun sirih merah (Piper crotacum ruiz dan pav) mempunyai daya hambat ter terhadap bakteri Propionibacterium acnes dan Staphylococcus aureus penyebab jerawat dan untuk menentukan konsentrasi kombinasi ekstrak kering lidah buaya (Aloe vera $(L)$ brum $f$ ) dan ekstrak kental daun sirih merah (Piper crotacum ruiz dan pav)mempunyai daya hambat terterhadap bakteri Propionibacterium acnes dan Staphylococcus aureus penyebab jerawat.Tahap-tahap penelitian yaitu determinasi tanaman lidah buaya dan daun sirih merah, pembuatan ekstrak, pemeriksaan ekstrak meliputi organoleptik, $\mathrm{pH}$, uji skrining fitokimia serta pengujian aktivitas masing-masing ekstrak kering lidah buaya dengan konsentrasi 10\%, 15\%, 20\%, $25 \%, 30 \%$ dan 35\%, ekstrak kental daun sirih merah dengan konsentrasi $25 \%, 12,5 \%, 7,16 \%$, $3,13 \%, 1,78 \%$ dan $0,78 \%$ serta kombinasi ekstrak kering lidah buaya dan ekstrak kental daun sirih merah dengan konsentrasi $50 \%, 25 \%, 12,5 \%, 7,16 \%, 3,13 \%$, dan 1,56 terhadap bakteri Propionibacterium acnes dan Staphylococcus aureus. Kombinasi ekstrak kering lidah buaya dan ekstrak kental daun sirih merah memiliki aktivitas antibakteri terhadap bakteri Staphylococcus aureus pada konsentrasi 1,56\% dan Propionibacterium acne pada konsentrasi 3,13

Kata kunci : Lidah buaya, daun sirih merah, Propionibacterium acnes, Staphylococcus aureus.

\begin{abstract}
Dried aloe vera extract and thick red betel leaf extract contains alkaloid compounds, flavonoids, tannins, saponins and phenols that have activity as an antibacterial cause of acne. The aim of this study was to determine the concentration of Aloe vera (L) brum $\mathrm{f}$ ) extract, to determine the thick red betel leaf extract (Piper crotacum ruiz and pav) to have the inhibitory effect against the bacteria Propionibacterium acnes and Staphylococcus aureus causes acne and to determine the concentration of Aloe vera (L) brum f) and red thick betel leaf extract (Piper crotacum ruiz and pav) have inhibitory effect on bacteria Propionibacterium acnes and Staphylococcus aureus cause acne. The research stages are the determination of aloe vera and red betel leaf, extract preparation, extract examination including organoleptic, $\mathrm{pH}$, phytochemical screening test and activity test of dry aloe vera extract with concentration $10 \%, 15 \%, 20 \%, 25 \%, 30 \%$ and $35 \%$, thick red betel leaf extract with concentration of $25 \%, 12.5 \%, 7.16 \%, 3.13 \%, 1.78 \%$ and $0.78 \%$, and combination of aloe vera extract and viscous extract red betel leaves with concentrations of 50\%, 25\%, $12.5 \%$, $7.16 \%, 3.13 \%$, and 1.56 against the bacteria Propionibacterium acnes and Staphylococcus aureus. The combination of dry extract of aloe vera and thick red betel leaf extract have antibacterial
\end{abstract}


activity against Staphylococcus aureus bacteria at concentration $1.56 \%$ and Propionibacterium acne at concentration $3,13 \%$.

Keywords: aloe vera, red betel leaf extract, Propionibacterium acnes, Staphylococcus aureus

Corresponding author:

Suhemi

Mahasiswa Fakultas Farmasi, Universitas Pancasila, Jakarta

Jl. Srengseng Sawah, Jagakarsa, Jakarta

Email : suhaimi.kalbar@yahoo.com

\section{PENDAHULUAN}

Kulit merupakan selimut yang menutupi permukaan tubuh dan memiliki fungsi utama sebagai pelindung dari berbagai macam gangguan dan rangsangan luar .Masalah kulit terutama dibagian wajah dapat menjadi masalah yang mengganggu penampilan, salah satunya jerawat karena kulit terus menerus berhubungan dan berkontak dengan lingkungan sekitarnya . Macammacam akne yaitu akne vulgaris, akne venenta, dan akne komedonal. Terjadi sekitar umur 14-17 tahun pada wanita 16-19 tahun pada pria pada masa itu lesi yang prodominan adalah komedo dan papul sehingga terjadinya peradang dipicu oleh bakteri Propionibacterium acnes, Staphylococcus epidermidis dan Staphylococcus aureus . Penyebab-penyebab jerawat yaitu pubertas, infeksi akibat sering memencet jerawat, alergi terhadap makanan dapat merangsang terjadinya jerawat, iklim dan polusi udara, makanan dan minuman, jiwa (stres), pola hidup, jenis kulit, keturunan, penggunaan kosmetik $^{5}$.Bakteri Propionibacterium acnes merupakan bakteri penyebab jerawat yang memiliki pertumbuhan yang relatif lambat. Bakteri Propionibacterium acnes hidup didaerah asam lemak di kantung kelenjar minyak (Sebaceous gland) pada kelenjar minyak (sebum) yang tersembunyi didalam pori-pori kulit, bakteri ini menghasilkan asam propionik yang dapat menyebabkan peradangan pada jerawat dan Staphylococcus aureus (S. aureus) berbentuk bulat atau lonjong, merupakan jenis yang tidak bergerak, tidak berspora, bakteri gram positif. Cara untuk pencegahan serta mengobati jerawat digunakan benzole peroksida, topikal treatment, tazarotene, tretinoin serta pemberian antibiotik doxycycline seperti trimethoprim kombinasi dengan sulfamethoxazole dan azithromycin Banyak tanaman yang mempunyai khasiat sebagai antijerawat diantaranya adalah tanaman jeruk nipis, mengkudu, lidah buaya, daun sirih merah, teh hijau, belimbing wuluh, mentimun, daun dewa, temulawak dan daun jeruk sambal.

Lidah buaya telah dikenal sebagai bahan untuk menyerap minyak pada kulit salah satunya untuk jerawat secara tradisional oleskan bagian daging dari lidah buaya secara merata dan menyeluruh pada permukaan wajah, diamkan sesaat kemudian membersihkan wajah cukup menggunakan air saja . Berdasarkan penelitian lidah buaya memiliki pengujian aktivitas ekstrak lidah buaya terhadap bakteri Propionibacterium acnes secara in vitro dengan konsentrasinya 50\% menghasilkan efek mengobati jerawat vulgaris . Kandungan tanaman lidah buaya yaitu semua jenis vitamin kecuali vitamin D, aloin, emodin, gum dan unsur lain seperti minyak atsiri. Senyawasenyawa gula juga terdapat pada lidah buaya dalam bentuk mannosa, glukosa, serta sejumlah kecil silosa, arabinosa, galaktosa, ramnosa serta enzim-enzim oksidase serta komponen nilai lidah buaya air $95.510 \%$, total padatan terlarut terdiri atas $0.0490 \%$, lemak $0.0670 \%$, karbohidrat $0.0430 \%$, Protein $0.0380 \%$, vitamin A $4.594 \mathrm{IU}$ dan Vitamin C $3.476 \mathrm{Mg} \cdot$ Konsentrasi lidah buaya yang akan digunakan untuk penelitian ini yaitu 10\%, 15\%, 20\%, 25\%, 30\% dan 35\%.

Sirih merah merupakan tanaman yang berkhasiat untuk mengatasi jerawat. mengandung flavonoid, alkaloid senyawa polifenolat, tanin dan minyak atsiri. Senyawa-senyawa diketahui memiliki sifat antibakteri. Konsentrasi yang akan digunakan yaitu 50\%, 25\%, 12.5 \%, 6.75\%, 3.13 $\%, 1,56 \%$ dan $0,78 \%$.

JIFFK Vol. 15, No. 1, JUNI 2018, Hal. 12 - 21 
Berdasarkan pernyataan di atas peneliti tertarik untuk meneliti kombinasi dan sirih merah dan lidah buaya terhadap bakteri staphylococcus aureus dan propionibacterium acnes penyebab jerawat.

\section{METODE PENELITIAN}

Bahan penelitian

Bahan yang digunakan dalam penelitian ini adalah Ekstrak kering lidah buaya ((Aloe vera. L)brum.f), Ekstrak kental daun sirih merah (Piper crocatum ruiz\& pav), etanol $96 \%$, bakteri, Nutrient agar, staphylococcus aureus dan propionibacterium acnes.

Alat Penelitian

Alat yang digunakan dalam penelitian ini adalah Timbangan analitik AND HR 120, Incubator (Memmert), spektrofotometer uv- vis, disponsibel $50 \mathrm{ml}$, Beaker glass (Pyrex), Gelas objek dan penutup, Oven, Lemari pendingin, Tabung reaksi (Pyrex), Otoklaf, Mikropipet 20 -200 dan $100-1000$.

\section{JALANNYA PENELITIAN}

1. Determinasi tanaman asal lidah buaya dan daun sirih merah

Tanaman asal lidah buaya (Aloe vera. L) brum.f) dan daun sirih merah (Piper crotacum ruiz \& pav) dideterminasi di Pusat penelitian Biologi Lembaga Ilmu Pengetahuan Indonesia (LIPI) Cibinong.

2. Pembuatan ekstrak tanaman lidah buaya (Aloe vera. L) brum.f) dan daun sirih merah (Piper crotacum ruiz \& pav)

3. Pemeriksaan kombinasi ekstrak kering lidah buaya dan ekstrak kental daun sirih merah

a. Pemeriksaan organoleptik ekstrak kering lidah buaya dan ekstrak kental daun sirih merah.

b. Pemeriksaan $\mathrm{pH}$ ekstrak kering lidah buaya dan ekstrak kental daun sirih merah

c. Uji Fitokimia ekstrak kering lidah buaya dan ekstrak kental daun sirih merah

d. Pemeriksaan rendemen dan pengujian ekstrak kering lidah buaya dan ekstrak kental daun sirih merah

e. Uji anti bakteri terhadap bakteri Propionibacterium acne dan Staphylococcus aureus

\section{ANALISIS DATA}

Analisis data penelitian ini ditampilkan berupa tabel dan kemudian di Diskripsikan

\section{HASIL DAN PEMBAHASAN \\ Determinasi}

Hasil determinasi lidah buaya dan daun sirih merah yang diperiksadi Pusat penelitian Biologi Lembaga Ilmu Pengetahuan Indonesia (LIPI) Cibinong, Menunjukan bahwa tanaman yang digunakan dalam penelitian ini adalah lidah buaya (Aloe vera (L.) Burm.f) dan daun sirih merah (Piper crotacum ruiz dan pav.

\section{Pemeriksaan karakteristik ekstrak kering lidah buaya dan ekstrak kental daun sirih merah Pemeriksaan organoleptis}

Tabel I Pemeriksaan Organoleptis

\begin{tabular}{cccc}
\hline Ekstrak & Warna & Bau & Bentuk \\
\hline Lidah buaya & cokelat muda & aromatik lidah buaya & Serbuk \\
Daun sirih merah & kuning kemerahan & aromatik sirih merah & ekstrak kental
\end{tabular}


Pemeriksaan organoleptis ekstrak kering lidah buayaberwarna cokelat muda berbau aromatik lidah buaya berbentuk serbuk dan ekstrak daun sirih merah berwarna kuning kemerahan berbau aromatik sirih merah berbentuk ekstrak kental, hasil organoleptis memenuhi persyaratan Materi Medika Indonesia.Hasil pemeriksaan organoleptis ekstrak kering lidah buaya dan ekstrak kentaldaun sirih merah.

\section{Pemeriksaan pH}

Tabel II. Pemeriksaan pHekstrak kering lidah buaya dan ekstrak kental daun sirih merah

\begin{tabular}{cc}
\hline Ekstrak & $\mathbf{p H}$ \\
\hline Lidah buaya & 6,65 \\
Daun sirih merah & 6,50 \\
\hline
\end{tabular}

Hasil pemeriksaan $\mathrm{pH}$ pada ekstrak kering lidah buaya dan ekstrak kental daun sirih merah dapat dilihat pada tabel II. menunjukan semua ekstrak mempunyai $\mathrm{pH}$ berada dalam rentang $\mathrm{pH}$ normal yang diperbolehkan untuk digunakan pada kulit yaitu 4,5-6,5. Pada ekstrak kering lidah buaya $\mathrm{pH}$ 6,65 dan ekstrak kering daun sirih merah 6,50 masih aman dan tidak mengiritasi kulit.

\section{Rendemen ekstrak dan pengujian ekstrak}

Rendemen ekstrak dan pengujian ekstrak kering lidah buaya dan ekstrak kental daun sirih merah sebagai berikut:

a. Ekstrak kental daun sirih merah

Rendemen ekstrak daun sirih merah adalah 13,7\% dapat dilihat pada lampiran 5. Berdasarkan pengujian kadar abu 1,02\%, kadar abu tidak larut asam $0,72 \%$, kadar sari larut dalam air $18.80 \%$, kadar sari larut dalam alkohol 78,66 \%, kadar air 16,63\% dan kadar minyak atsiri 0,30\% sedangkan berdasarkan Farmakope Herbal Indonesia kadar abu tidak lebih dari 14\%, kadar abu tidak larut asam tidak lebih dari 7\%, kadar sari larut air tidak kurang dari 14\%, kadar sari yang larut etanol tidak kurang dari 4,5\%. Hasil pengujian ekstrak daun sirih merah memenuhi syarat Farmakope Herbal Indonesia.

b. Ekstrak kering lidah buaya

Berdasarkan rendemen ekstrak lidah buaya adalah 21,217 \% dapat dilihat pada lampiran 5 dan pengujian kadar air 6,57\%, kadar abu 0,58\%, kadar abu tidak larut asam 0,31\%, kadar sari larut dalam air 91,44\% dan kadar sari larut dalam alkohol 2,29\%sedangkan berdasarkan Farmakope Herbal Indonesia kadar abu total tidak lebih dari 1,5\%, abu tidak larut dalam asam tidak lebih dari $0,9 \%$, sari larut air tidak kurang dari 1,4\% dan sari larut etanol tidak kurang dari 2,3\%. Hasil pengujian ekstrak lidah buaya memenuhi syarat Farmakope Herbal Indonesia. 


\section{Uji skrining fitokimia ekstrak keringlidah buaya dan ekstrak daun sirih merah}

Tabel III. .Hasil uji skrining fitokimia ekstrak kering lidah buaya dan ekstrak kentaldaun sirih merah.

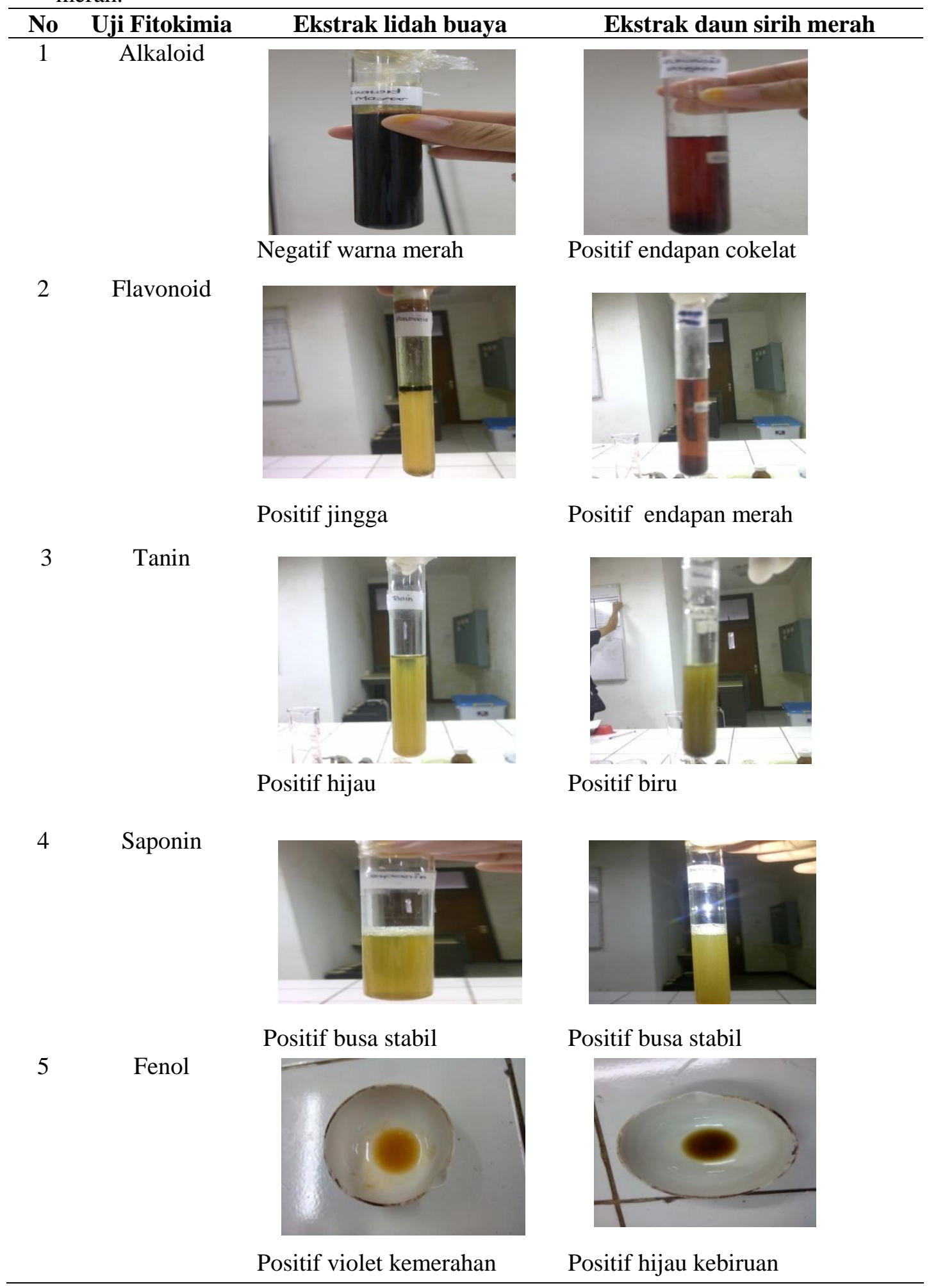

Uji Aktivitas kombinasi ekstrak kering...(Suhemi et al.,' 
Hasil skrining fitokimia dapat dilihat pada tabel III.Ekstrak kering lidah buaya positif mengandung flavonoid, tanin, saponin dan fenol sedangkan senyawa alkaloid negatif.Senyawa flavonoid ditandai dengan terbentuknya warna kuning setelah penambahan hidroklorida pekat, tanin ditandai dengan terbentuknya warna hijau setelah penambahan $\mathrm{FeCl}_{3} 1 \%$, saponin ditandai dengan terbentuknya busa $\pm 2 \mathrm{~cm}$ yang stabil tidak kurang dari 10 menit, senyawa fenol ditandai dengan terbentuknya warna merah bata dengan penambahan $\mathrm{FeCl}_{3} 1 \%$. Ekstrak lidah buaya dari hasil skrining fitokimia tidak menunjukan adanya senyawa alkaloid karena setelah penambahan pereaksi wagner dan mayer tidak terbentuk warna putih dan endapan cokelat.

Hasil skrining fitokimia dapat dilihat pada tabel III. ekstrak kental daun sirih merah positif mengandung alkaloid, flavonoid, tanin, saponin dan fenol. Senyawa alkaloid ditandai terbentuknya endapan cokelat dengan penambahan pereaksi wagner, senyawa flavonoid ditandai dengan warna merah setelah penambahan hidroklorida (HCL) pekat, senyawa tanin ditandai dengan terbentuknya warna hijau dengan penambahan $\mathrm{FeCl}_{3} 1 \%$, senyawa saponin ditandai dengan terbentuknya busa \pm $3 \mathrm{~cm}$ yang stabil tidak kurang dari10 menit, senyawa fenol ditandai dengan warna hijau kebiruan dengan penambahan $\mathrm{FeCl}_{3} 1 \%$.

\section{Hasil uji aktivitas ekstrak kering lidah buaya dan ekstrak kentaldaun sirih merah terhadap bakteri Propionibacterium acnedan Staphylococcus aureus.}

Hasil uji aktivitas ekstrak lidah buaya dan ekstrak daun sirih merah terhadap bakteri Propionibacterium acne dan Staphylococcus aureusdapat dilihat pada tabel IV Ekstrak kental daun sirih merah.

Tabel IV. Hasil uji aktivitas pertumbuhan bakteri pada ekstrak kental sirih merah terhadap bakteri Propionibacteriumacne

\begin{tabular}{cccc}
\hline Bakteri uji & $\begin{array}{c}\text { Konsentrasi } \\
(\%)\end{array}$ & \multicolumn{2}{c}{ Propionibacterium acne } \\
\hline P. acne & 25 & - & Media II \\
\hline 12,5 & - & - \\
6,25 & - & - \\
3,13 & + & + \\
1,56 & + & + \\
0,78 & + & + \\
$-*$ & + & + \\
$+*$ & - & - \\
\hline
\end{tabular}

\footnotetext{
Keterangan: $-^{*}=$ Kontrol negatif $\quad *^{*}=$ kontrol positif

- = konsentrasi bisa membunuh bakteri,

$+=$ konsentrasi tidak membunuh bakteri
} 
Tabel V. Hasil uji aktivitas pertumbuhan bakteri pada ekstrak kental daun sirih merah terhadap bakteri Staphylococcus aureus.

\begin{tabular}{lccccccc}
\hline \multirow{2}{*}{ Bakteri } & \multirow{8}{c}{ Konsentrasi (\%) } \\
& Pengulangan & 0,78 & 1,56 & 3,13 & 6,25 & 12,5 & 25 \\
\hline \multirow{3}{*}{ S. aureus } & 1 & + & + & + & + & 1,2 & 1,5 \\
& 2 & + & + & + & + & 1,2 & 1,7 \\
& Rata-rata & 0 & 0 & 0 & 0 & 1,2 & 1,6 \\
& STDEV & 0 & 0 & 0 & 0 & 0 & 0,1 \\
\hline
\end{tabular}

Keterangan: $+=$ konsentrasi tidak membunuh bakteri

Hasil uji aktivitas pertumbuhan bakteri pada ekstrak kering lidah buaya dan ekstrak kental daun sirih merah dapat dilihat pada tabel V.5 dan lampiran 13.Ekstrak daun sirih merah memiliki potensi antibakteri terhadapPropionibacterium acne danStaphylococcus aureus. Konsentrasi yang di uji yaitu $25 \%, 12.5 \%, 6.25 \%, 3.13 \%, 1.56 \%$ dan $0.78 \%$. Ekstrak sirih merah terhadap bakteri Propionibacterium acne pada konsentrasi 25\%, 12,5\% dan 6,75\% hasil negatif hal ini menunjukan bahwa pada konsentrasi tersebut memiliki daya hambat terhadap bakteriPropionibacterium acnedan pada konsentrasi $3,13 \%, 1,56 \%$ dan $0,78 \%$ positif hal ini menunjukan bahwa konsentrasi tersebut tidak menunjukan adanya diameter daya hambat terhadap bakteri Propionibacterium acne, sedangkan pada bakteri Staphylococcus aureus ada zona bening terhadap konsentrasi 25\% dan $12,5 \%$ memiliki diameter daya hambat (DDH) sedangkan pada konsentrasi 6,25 \%, 3.13\%, 1,56\% dan $0,78 \%$ tidak ada zona bening hal ini menunjukan tidak memiliki diameter daya hambat (DDH). Konsentrasi yang digunakan untuk kombinasi ekstrak sirih merah terhadap Propionibacteriumacne konsentrasi 25\% dan Staphylococcus aureus konsentrasi 12,5\%.Sehingga dalam penelitian ini untuk mengkombinasi ekstrak kental daun sirih merah dan ekstrak kering lidah buaya.

Tabel V. Hasil uji aktivitas pertumbuhan bakteri pada ekstrak kering lidah buaya terhadap bakteri Propionibacteriumacne dan Staphylococcus aureus

\begin{tabular}{cccccccccc}
\hline $\begin{array}{c}\text { Bakteri } \\
\text { uji }\end{array}$ & Pengulangan & \multicolumn{6}{c}{ Diameter Daya Hambat (DDH) } \\
& & $\boldsymbol{+}^{*}$ & $\boldsymbol{*}_{\mathbf{-}}$ & $\mathbf{1 0}$ & $\mathbf{1 5}$ & $\mathbf{2 0}$ & $\mathbf{2 5}$ & $\mathbf{3 0}$ & $\mathbf{3 5}$ \\
\hline \multirow{4}{*}{ P. acne } & I & 1.6 & - & + & + & + & 1 & 1.5 & 1.5 \\
& II & 1.6 & - & + & + & + & 1.2 & 1.4 & 1.4 \\
& Rata - rata & 1.6 & 0 & 0 & 0 & 0 & 1.1 & 1.45 & 1.45 \\
& STDEV & 0.1 & 0 & 0 & 0 & 0 & 0.1 & 0.5 & 0.5 \\
S. aureus & I & 1.4 & - & + & + & + & 1.9 & 2 & 2.2 \\
& II & 2.3 & - & + & + & + & 1.9 & 1.9 & 2.1 \\
& Rata -rata & 1.85 & 0 & 0 & 0 & 0 & 1.9 & 1.95 & 2.15 \\
& STDEV & 0.45 & 0 & 0 & 0 & 0 & 0.05 & 0.05 & 0.05 \\
\hline
\end{tabular}

Keterangan: $\left(-^{*}\right)=$ Kontrol negatif $\left(+^{*}\right)=$ Kontrol positif

-= konsentrasi bisa membunuh bakteri,

$+=$ konsentrasi tidak membunuh bakteri

Hasil uji aktivitas pertumbuhan bakteri pada ekstrak lidah buaya dan ekstrak daun sirih merah dapat dilihat pada tabel V.Ekstrak lidah buaya terhadap Propionibacterium acne memiliki zona bening pada konsentrasi 25\%, 30\% dan 35\% dan pada konsentrasi 20\%, 15\% dan 10\% tidak memiliki diameter daya hambat dan pada bakteri Staphylococcus aureus konsentrasi 35\%, 30\% dan $25 \%$ memiliki zona bening hal ini menandakan memiliki aktivitas terhadap bakteri, sedangkan pada konsentrasi $10 \%, 15 \%$ dan $20 \%$ tidak memiliki zona bening hal ini menandakan konsentrasi tersebut tidak memiliki aktivitas sebagai antibakteri.Kemudian konsentrasi yang akan digunakan 
untuk kombinasi ekstrak kering lidah buaya dan ekstrak kentaldaun sirih merah terhadap bakteri Propionibacterium acnekonsentrasi 25\% dan terhadap bakteri Staphylococcus aureus konsentrasi $25 \%$.Sehingga dalam penelitian ini dilanjutkan untuk mengkombinasikan ekstrak kering lidah buaya dan ekstrak kental daun sirih merah.

\section{Uji aktivitas kombinasi ekstrak kering lidah buaya dan ekstrak kental daun sirih merah}

Tabel VI. Uji aktivitas kombinasi ekstrak kering lidah buaya dan ekstrak kentaldaun sirih merah terhadap bakteriPropionibacteriumacnedan Staphylococcus aureus

\begin{tabular}{cccccccccc}
\hline \multirow{3}{*}{ Bakteri uji } & Pengulangan & \multicolumn{7}{c}{ Diameter Daya Hambat (DDH) } \\
& & $\boldsymbol{+}^{*}$ & $\mathbf{- *}$ & $\mathbf{1 , 5 6}$ & $\mathbf{3 , 1 3}$ & $\mathbf{6 , 2 5}$ & $\mathbf{1 2 , 5}$ & $\mathbf{2 5}$ & $\mathbf{5 0}$ \\
\hline \multirow{4}{*}{ P. acne } & I & 2.1 & - & + & 1.1 & 1.3 & 1.4 & 1.6 & 1.8 \\
& II & 2.1 & - & + & 1 & 1.3 & 1.4 & 1.5 & 1.8 \\
& Rata - rata & 2.1 & 0 & 0 & 1.05 & 1.3 & 1.4 & 1.55 & 1.8 \\
& STDEV & 0 & 0 & 0 & 0.05 & 0 & 0 & 0.05 & 0.05 \\
S. aureus & I & 2.3 & - & 1 & 1.4 & 1.4 & 1.5 & 1.7 & 1.8 \\
& II & 2.5 & - & 1.2 & 1.3 & 1.5 & 1.5 & 1.7 & 1.8 \\
& Rata - rata & 2.4 & 0 & 1.1 & 1.35 & 1.45 & 1.5 & 1.7 & 1.8 \\
& STDEV & 0.1 & 0 & 0.1 & 0.05 & 0.05 & 0 & 0.05 & 0.05 \\
\hline
\end{tabular}

keterangan : $(-)=$ Kontrol positif $(+)=$ Kontrol negatif

- = kosentrasi bisa membunuh bakteri, $+=$ konsentrasi tidak membunuh bakteri

Hasil uji aktivitas pertumbuhan kombinasi dari ekstrak kering lidah buaya dengan konsentrasi $25 \%$ dan ekstrak kental daun sirih merah dengan kosentrasi 12,5\% dapat dilihat pada tabel Uji aktivitas dengan kombinasi ekstrak lidah buaya dan ekstrak daun sirih merah terhadap bakteri Staphylococcus aureus dengan konsentrasi 50\%, 25\%, 12.5\%, 6.75\%, 3.13\% dan 1.56\% memiliki diameter daya hambat dan terhadap bakteri Propionibacterium acnes dengan konsentrasi $50 \%, 25 \%, 12.5 \%, 6.75 \%, 3.13 \%$ dan $1.56 \%$ pada konsentrasi $1.56 \%$ tidak memiliki diameter daya hambat. karena cenderung stabil dan konsisten serta kadar hambat minimal (KHM) konsentrasi terkecil sudah memberikan diameter daya hambat (DDH).

\section{KESIMPULAN}

Ekstrak kering lidah buaya yang memiliki diameter daya hambat pada konsentrasi 25\%, 30\% dan 35\% terhadap bakteri Propionibacterium acnes dan Staphylococcus Aureus. Ekstrak sirih merah yang memiliki diameter daya hambat pada konsentrasi 0,78\% terhadap bakteri Propiobacterium acnes dan konsentrasi 12,5 \% terhadap Staphylococcus Aureus. Kombinasi ekstrak kering lidah buaya dan ekstrak kental daun sirih merah memiliki aktivitas antibakteri terhadap bakteri Staphylococcus aureus pada konsentrasi $1,56 \%$ dan Propionibacterium acne pada konsentrasi 3,13\%, 6,25\%, 12,5\%, $25 \%$ dan $50 \%$.

\section{UCAPAN TERIMA KASIH}

Peneliti mengucapkan terima kasih kepada orang tua, Prof. Teti Indrawati . M. Si., Apt dan Prof, Shirly Kumala. Apt, M. Biomed sebagai dosen pembimbing yang telah sabar membimbing kepada peneliti. 


\section{DAFTAR PUSTAKA}

Tranggono IR, Latifah. 2007.Buku Pegangan Kosmetik. Jakarta: PT Gramedia Pustaka. h. 11

Oswari E. 2006. Penyakit dan Penanggulangan. Jakarta: Fakultas Kedokteran Universitas Indonesia. .h. 122

Djuanda A, Hamzah M. Aisah.2007.Ilmu Penyakit Kulit dan Kelamin edisi IV. Jakarta. Fakultas Kedokteran Universitas Pancasila Press.h.235

Jawet E, Melnick. J. Adebert EA.1996. Mikrobiologi Kedokteran Edisi XX. Jakarta:ECG. h. 188 - 9

Tranggono R. 1997. Jerawat Pada Pencegahan dan Penanggulangannya Symposium "Jerawat Pubertas dan Perkawinan". Jakarta: Pusat Dokumentasi dan Informasi Ilmiah.POCI. LIPI 1-3

Vera. Purwati. 2010. Uji aktivitas Antibakteri Penyebab Antijerawat Dari daun dewa. Padang: Fakultas Farmasi Universitas Andalas Padang. h. 92 -3

Morsy, EM. 2010. Aloe vera Stabilization and Processing for The Cosmetic Beverage and Food Industries, Fifth edition,. Citra Interna-tional, USA (diakses Jakarta, 6 September 2013)

Terapi Alam, Mengobati Jerawat dengan Cara Alami. Diambil dari: http:/terapialammengobatijerawatdengancaraalami (Di akses, 26 September 2013).

Hajheydari Z, Saeedi M, Morteza-semnani K, Soltani A. 2013. Journal Dermatology Treat. Effect Of Aloe Vera Topical Gel Combined With Tretnoin in treatment Of Mild And Moderate acne Vulgaris: A Randomized Double - Blind, Prospective Trial. Departement Of Dermatologiy, Boo Ali Sina (Avicenne) Hospital, Faculty Of Medicine, Mazandaran University Of Medical Sciences. Sari. Iran. . (diakses Jakarta: 21 September 2013).

Fowlerjoe. Journal Drug 2010. Dermatology Inovations in Natural Ingrediests and their use in skin care.University Of Louisville, Division Of Dermatology, Louisville, Ky 40202, USA (Diakses Jakarta: 21 September 2013).

Mardiana lina. 2012. Daun Ajaib Tumpas Penyakit. Jakarta. PT: Penebar Swadaya. h.116-118 Achmad dan Ido Suryana. 2010. Pengujian Aktivitas Ekstrak Daun Sirih (piper betle) terhadap Rizhoma Sp. Secara Invitro. Bogor: Departemen Manajemen Hutan Fakultas Kehutanan. Institut Pertanian Bogor.

Juliantina Farida, DKK. 2010. Manfaat Sirih Merah (Piper crocatum) sebagai Agen Antibakteria terhadap Bakteri Proniobacterium acnes dan Staphylococcus aureus. Jurnal Kedokteran dan Kesehatan Indonesia. (di Akses Jakarta : 29 September 2013).

Departemen Kesehatan RI. 2008. Farmakope Herbal Indonesia Edisi 1. Jakarta: Departemen Kesehatan RI. h. 85-87

Santoso, H.B.2008. Ragam dan khasiat Tanaman Obat. Cet 1. Jakarta: Agro Media Pustaka. h 7178

Fitriani Anti, Winarti L, DKK. 2011. Uji Anti Inflamasi Ekstrak Metanol Daun Sirih Merah (Piper crocatum) pada Tikus Putih. Majalah Obat Tradisional. 34-42 (diakses Jakarta: 6 September 2013). 
Harahap M. editor. 1998. Ilmu Penyakit Kulit. Jakarta: Penerbit Hipokrates. h.36,37

Pelejer MJ. Reid RD. Dasar-dasar Mikrobiologi. Edisi I diterjemahkan Oleh Hadietamo RS. Imas T, Tjitrosomo Angka SL. Jakarta: Universitas Indonesia. h. 489 -522

British Pharmacopeia. 1993. British Pharmacopeia Commision Volume II. London: Her stationery Office. H 167-8

Unitet States Pharmacoeial Convention. The Unitet States Phamacoeia 26 - antibiotics-Micrbial Assay/Biological Test. Rockville: Unitet States Pharmacopeia Convention Inc. hal 2022.

Oprica, C.2014.Antibiotic-Resistent Provionibacterium Acnes On the Skin Of Patient With Moderate to severe Acne. Journal Of Phamacology. h. 155-164 (Di akses, Jakarta 7 Februari 2014)

Akiyama H. Fuji K, Yamaski O dan Iwatsuki T. 2011 Antibaterial Actioon Of Deveral Tannin Against Staphylococcus aureus. Journal Of Antimicrobial Chemotherapy. h. 487 -91

JIFFK Vol. 15, No. 1, JUNI 2018, Hal. 12 - 21 